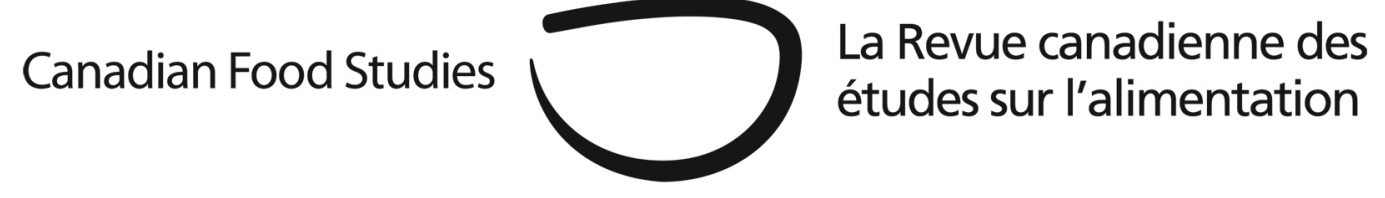

Original Research Article

\title{
Forever young? The crisis of generational renewal on Canada's farms
}

\author{
Darrin Qualman ${ }^{1}$, A. Haroon Akram-Lodhi ${ }^{2}$, Annette Aurélie Desmarais ${ }^{3}$, and \\ Sharada Srinivasan ${ }^{4}$
}

${ }^{1}$ Independent researcher and writer ${ }^{2}$ Department of International Development Studies, Trent University ${ }^{3}$ Department of Sociology and Criminology, University of Manitoba ${ }^{4}$ Department of Sociology and Anthropology, University of Guelph

\begin{abstract}
There are fewer and fewer young people actively farming in Canada. Farmers under the age of 35 are leaving farming at twice the rate of the general farm population. As a result, Canada faces a crisis of generational renewal on its farms. This article explores the factors that mitigate against young people taking up farming. Using an analytical framework in part derived from the work of Henry Bernstein and applied to Statistics Canada data, the article demonstrates that there is an ongoing income crisis, a growing problem of farmland accessibility and costs associated with farm machinery, unrestrained increases in the power and profit-share of agribusiness transnationals, and a retreat of governments from public-interest regulation. In doing so, the article provides an evidence-based analysis of the structural factors and forces driving Canada's crisis of generational renewal on its farms.
\end{abstract}

Keywords: Agriculture in Canada; farm policy; young farmers 


\section{Introduction ${ }^{1}$}

In terms of the number of farms, Canadian agriculture is a shrinking sector. This is illustrated in Figure 1, which shows a one-third reduction in the number of Canadian farms between 1986 and 2016 and a loss of two-thirds of Canadian farms since the 1950s. The trend line is relentlessly downwards. Nearly all of the loss of farms is due to farm consolidation. Only a small part of the loss may be due to shrinkage in Canada's farmland base.

With declining farm numbers comes declining numbers of farm operators. In Canada, since the mid-1980s, there has been a loss of one-third of Canadian farm families. There is, however, an aspect to this decline in farm operators that is not widely recognized and which is crucial to the future of Canada's ability to feed itself. This aspect of the decline is shown in Figure 2, which illustrates the reduction in the number of farm operators under the age of 35.

Figure 1: Number of farms (“farm operations”), Canada, 1911 to 2016, Census years

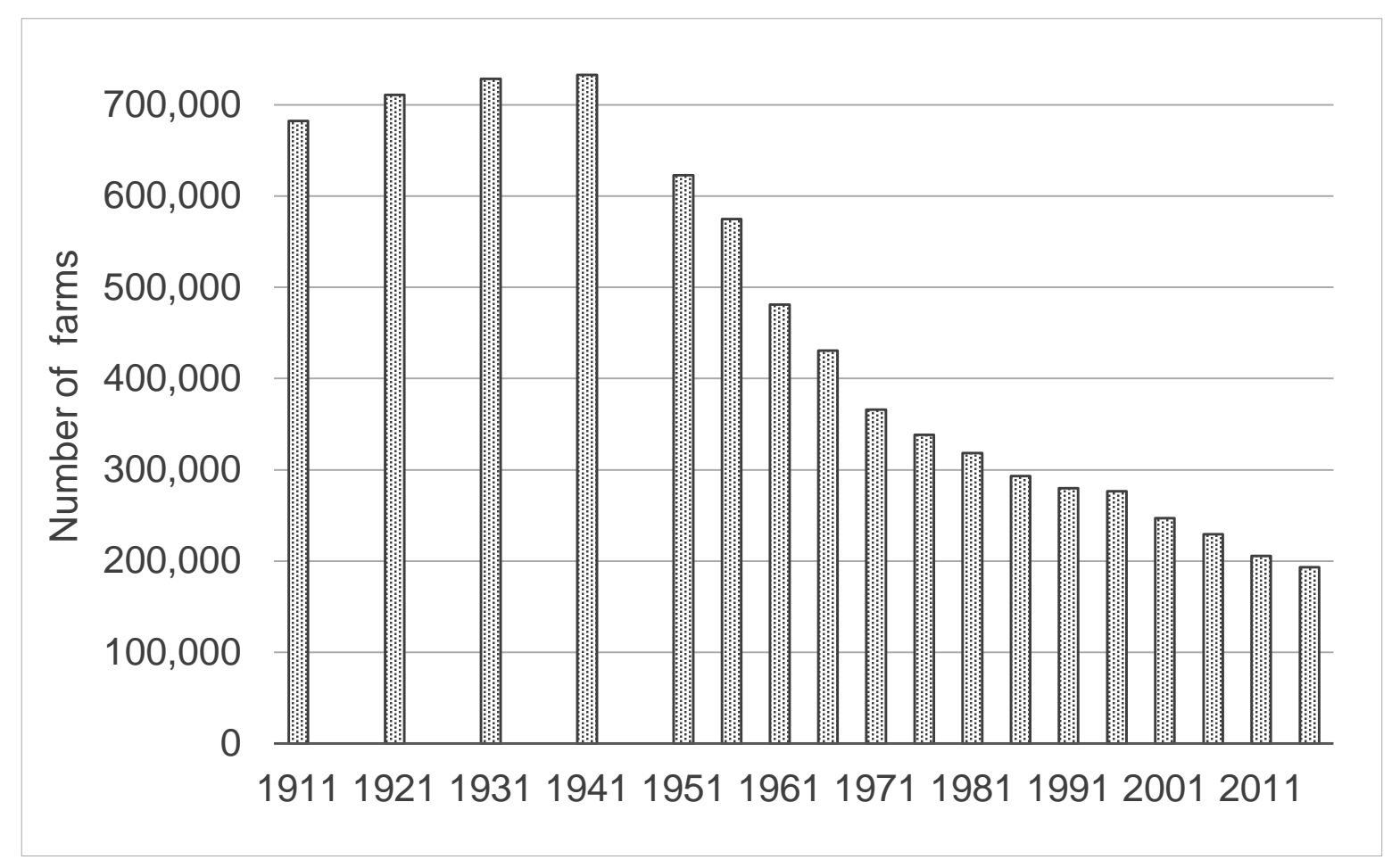

Source: Statistics Canada (2018a)

1 This article is part of the research "Becoming a young farmer: young people's pathways into farming" funded by the Social Sciences and Humanities Research Council (SSHRC), Canada. 
Figure 2: Number of farm operators under 35, Canada, 1991 to 2016, Census years

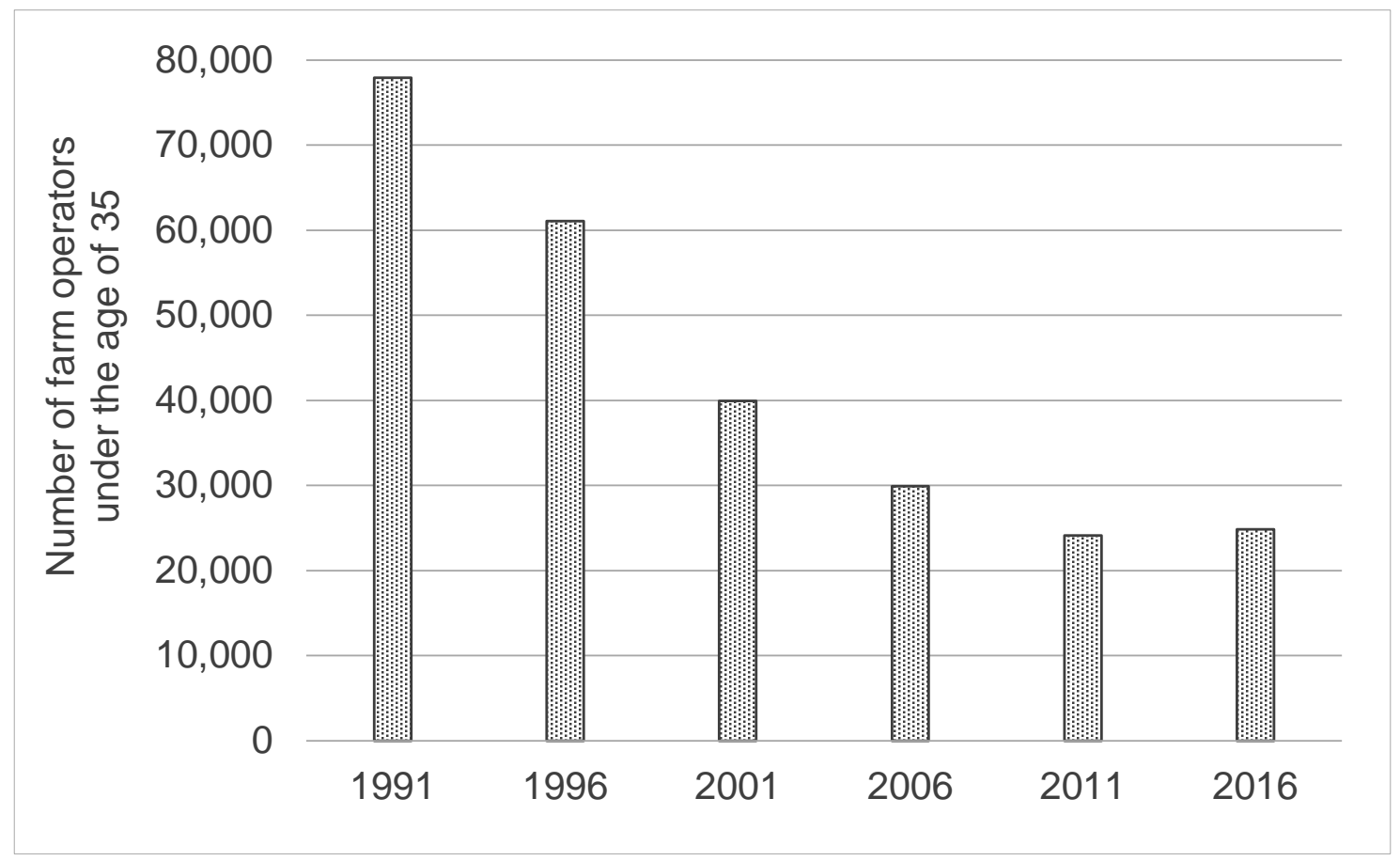

Source: Statistics Canada (2018b); and Beaulieu (2014)

Figure 2 shows that there has been a nearly 70 percent decline in the number of farmers aged 15 to 34, inclusive, over the past 25 years. This means that Canada is losing young farmers at twice the rate that it is losing farmers overall. Clearly, Canada faces a looming problem of generational renewal on its farms. Unless new policies and programs are introduced to ensure that young people can enter farming and that they can remain on the land, Canadian agriculture risks plunging off a demographic cliff.

This then is the purpose of our article: to better understand the factors that mitigate against young people taking up farming or remaining in the profession. More specifically, we argue that there are a number of key underlying structural factors and forces in Canadian agriculture that have an important effect in shaping the individual behavioural choices of young people, which results in a disinclination to consider farming as a livelihood. The article identifies four key structural factors: low net incomes, an imbalance in market power between farmers and agribusiness corporations, increasingly unaffordable farmland, and corporate- rather than farmerfocused state regulatory regimes. The effect of these structural factors on the next generation of farmers warrants serious attention, given the generational crisis in Canada's agriculture. We argue that the evidence points to the need for a radical shift in agricultural and food policy to deal with the pathologies that are reducing farm numbers overall, and to encourage the entry of young people into farming, if an intensification of a farm crisis is to be averted. We believe that a democratic, bottom-up process is the most effective and legitimate way to craft those new food and agricultural policies. 


\section{Analytical framework}

To analyze why the number of farmers, young and old, is declining, we use the analytical perspective of agrarian political economy that centres on: "the social relations and dynamics of production and reproduction, property and power in agrarian formations and their processes of change, both historical and contemporary” (Bernstein, 2010, 1). In particular, the article focuses on what Bernstein $(2010,22)$ calls the four key questions of agrarian political economy: Who owns what? Who does what? Who gets what? What do they do with it? Bernstein argues that these four questions allow a broad understanding of the structural factors that shape farm production and agriculture in a range of societies. However, in this article we will not investigate "what do they do with it", because, as will be seen, this would require an analysis of corporate reinvestment strategies that, although critically important, is beyond the scope of this paper. Additionally, rather than following Bernstein's three questions seriatim, we begin with an examination of farm incomes followed by a focus on farm land and other capital, and come back to the question of work. We proceed in this order because the issue of farm income-who gets what? - is foundational to other considerations, including land prices and ownership, debt, and barriers to young people entering or remaining in agriculture. We have also added our own fourth question to the enquiry: what is the role of the state in facilitating the structural processes that are in evidence?

\section{Who gets what?}

\section{The income problem}

We begin this section by first explaining the three key terms used when discussing net farm income. (1). Net farm income is the amount of money farmers have left after they pay their production costs. It is not the same as profit, as it is, in most cases, calculated before allowances are made for farm family labour and management. Out of net income, many farm families must pay themselves, pay off debt principle, and pay off the capital cost of land purchases. (2). Of the various measures of net farm income, realized net farm income best reflects farmers' situation, taking into account depreciation on machinery and other capital assets and income-in-kind (the value of food produced and consumed on the farm). (3). Realized net farm income from the markets (or "realized net farm income, net of state payments") is realized net farm income with taxpayer-funded farm-support program payments subtracted out. This is done to remove the masking effect such payments can create. Admittedly, this understates the amount of money that farm families have to live on-because it subtracts support payments-but by doing so it reveals the economic realities of the agricultural markets upon which many farm families must depend.

The analysis that follows will make the case that insufficient net farm income is the most significant factor impeding the entry of young farmers, forcing the exit of young farmers, and 
creating strains for many young farmers who struggle to remain in the sector. Low net farm income is the main reason that Canada has lost one-third of its farms since 1986 and two-thirds of its young farmers since 1991.

If we add up Canadian realized net farm income from the markets in the 22-year period from 1986 to 2007, the sum is zero; positive returns in some years were wholly offset by losses in others. During that period, for most farm families, most or all of their household incomes came from off-farm employment, pensions, taxpayer-funded farm-support programs, asset sales, depreciation, and borrowed money (see Figures 3, 13, and 14). During that time, farmers produced and sold agricultural products with a gross value of $\$ 820$ billion, but expenses (mostly payments to input manufacturing corporations) consumed that entire amount (Statistics Canada, 2018c; 2018d; 2018e).

Looking over a longer period — the 31 years encompassing 1986 to 2016, inclusive-the picture is only slightly better. During that time, farmers were able to retain only two percent of their gross revenues from the markets (i.e., with state subsidies subtracted out); inputs makers and other corporations captured the other 98 percent. Figure 3 shows Canadian farmers' gross revenues and net income over the past 90 years. Note the growing gap between the top line (the revenues farmers generated by producing and selling products) and the bottom line (the net income farmers got to keep). That widening gap graphically depicts the growing share of farmgenerated wealth captured by machinery, fertilizer, chemical, seed, and energy companies; banks and financial institutions; and by accountants, veterinarians, agrologists, and other service providers.

Figure 3: Canadian gross farm revenues from the market and realized net farm income from the market, adjusted for inflation, 1926 to 2016

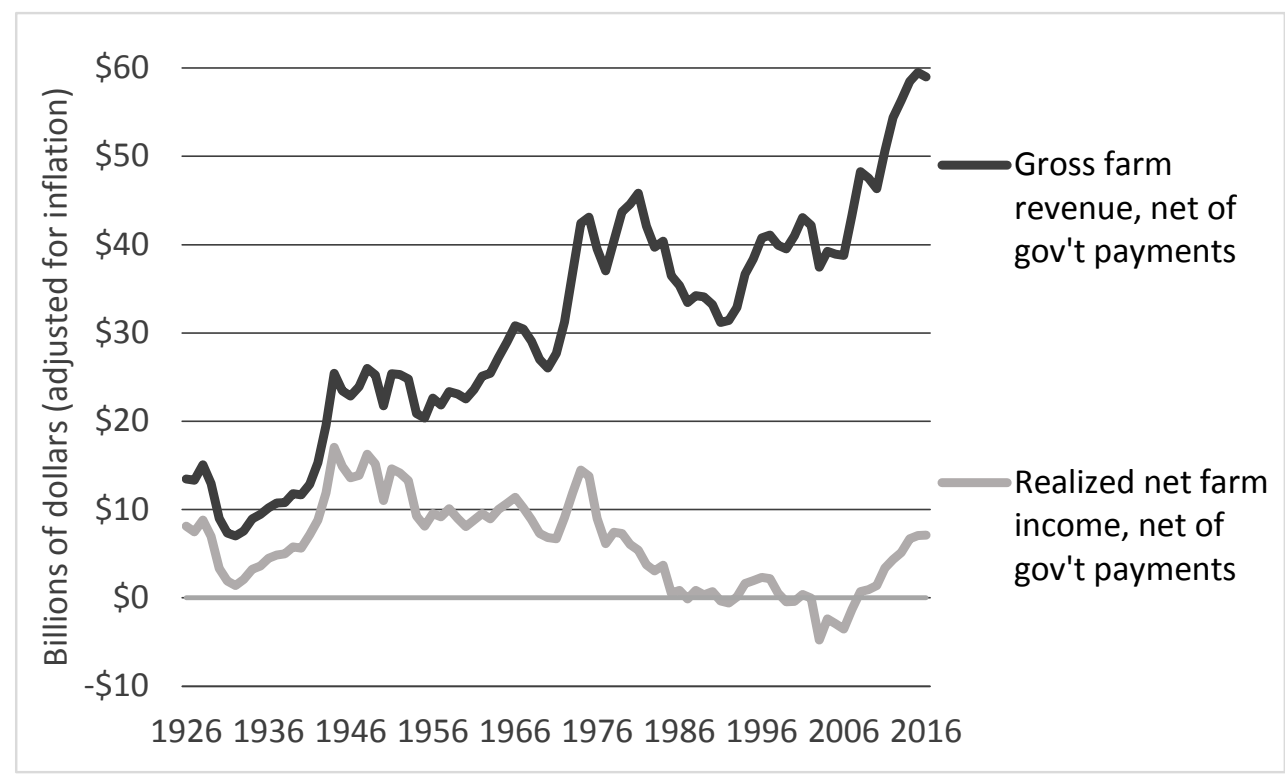

Sources: Statistics Canada (2018c; 2018d; 2018e; 2018f) 
The problem of low net farm income is connected to (or a result of) several other factors:

- $\quad$ the imbalance in market power between farmers and agribusiness transnationals;

- $\quad$ state policies too focused on maximizing production and exports and, hence, too supportive of maximizing farmers' use of purchased inputs and technologies;

- commodity prices that, adjusted for inflation, have trended sharply downward for decades;

- farm debt that has now risen to record levels, and continues to climb;

- $\quad$ the chronic need to transfer taxpayer dollars to our family farms; and

- the declining capacity of the sector to financially support a reasonable number of farm families from net farm income.

We examine each of these points below, by providing details and examples.

Net farm income inequality

Not only is net farm income low, it is distributed inequitably. Twenty percent of Canadian farms (those with revenues near or above $\$ 500,000$ annually) capture approximately 80 percent of net income.

Figure 4: Canadian net farm income shares, by revenue class, 2014. Note that net income is net of government subsidies and capital cost allowance (CCA)

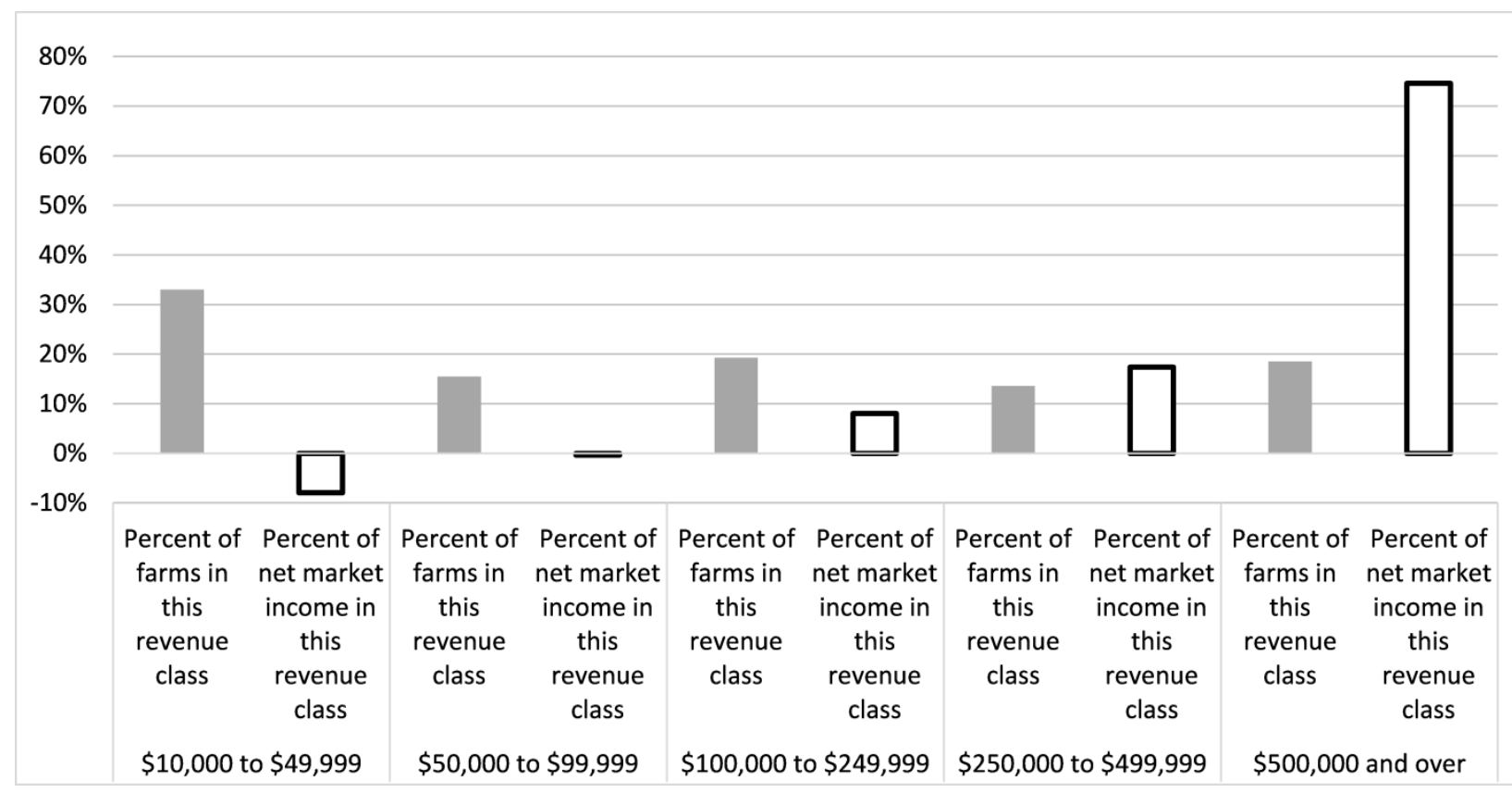

Source: Statistics Canada (2018g) 
Figure 4 divides Canadian farms by revenue categories: $\$ 10,000$ to $\$ 49,999$ in annual revenues, $\$ 50,000$ to $\$ 99,999$, and so on. The data is for the year 2014 , but almost all recent years would appear similar. The grey bars show the percentage of Canadian farms that fall within each revenue category. The white bars show the percentage of net market income, adjusted for capital cost allowance, earned by farms in each revenue category. (This measure is approximately equal to "realized net income from the markets.")

For example, looking at the bars in the middle, those representing farms with revenues between $\$ 100,000$ and $\$ 249,999$, the gray bar shows that farms in this revenue category make up just under 20 percent of Canadian farms. (see the centre-most gray bar). The white bar shows that farms in this revenue category collected just under 10 percent of all farm revenues (see centre-most white bar).

Note the two bars on the right, those for farms with annual revenues above $\$ 500,000$. This category includes some very large farms, indeed, with revenues reaching into the tens-of-millions of dollars per year. In 2014, farms in this category made up only 19 percent of Canada's total, but captured 75 percent of net market income (a similar imbalance is present in all other recent years). At the other end of the income spectrum, adding up the net market income for the three categories on the left — those with revenues stretching from $\$ 10,000$ to $\$ 249,000$ annually — we get zero; the small amount of positive revenue in the third category is cancelled out by equivalent losses in the first. But these three categories together account for 68 percent of Canadian farms. The problem of overall low net farm income is compounded by the fact that the little net income that exists is captured by the largest farms. The markets provide almost no net income to small and mediumsized farms. Though data is not available on young farmers' incomes segmented by income category, Figure 4 makes clear that there exists a huge obstacle to anyone, young or old, wishing to establish their own independent farm operation, as most of those operations start out small or medium-sized.

\section{Rising debt}

Canadian farm debt is at a record high, and rising. Adjusted for inflation, debt has nearly tripled since the early 1990s, as shown in Figure 5. Perhaps most troubling, levels continued to rise after 2007, even though the period since then has been, by some assessments, one of "better times" for farmers.

Rising debt reflects both the paucity of net farm income and the very high capital requirements for many types of farm operations (more on this latter factor below). Both of these factors-low margins and high costs - make it hard for young farmers to enter the sector or, once in, to continue. Indeed, mounting farm debt may create an existential threat to Canadian agriculture as a whole. Realized net farm income from the markets - the money that farmers have left from their crop and livestock sales after they pay their expenses - has averaged just $\$ 3.5$ billion annually over the past 10 years, and just $\$ 1.2$ billion annually over the past 20 . With net income from the markets at these levels, farmers' capacity to service nearly $\$ 100$ billion in 
debt is limited, and their capacity to repay that debt from net income appears to be very small. Indeed, the trend line suggests that debt will continue to increase. A farm income crisis may be setting the stage for a farm debt crisis - a key precipitating factor of the generational crisis.

Figure 5: Canadian farm debt, adjusted for inflation, 1971-2016

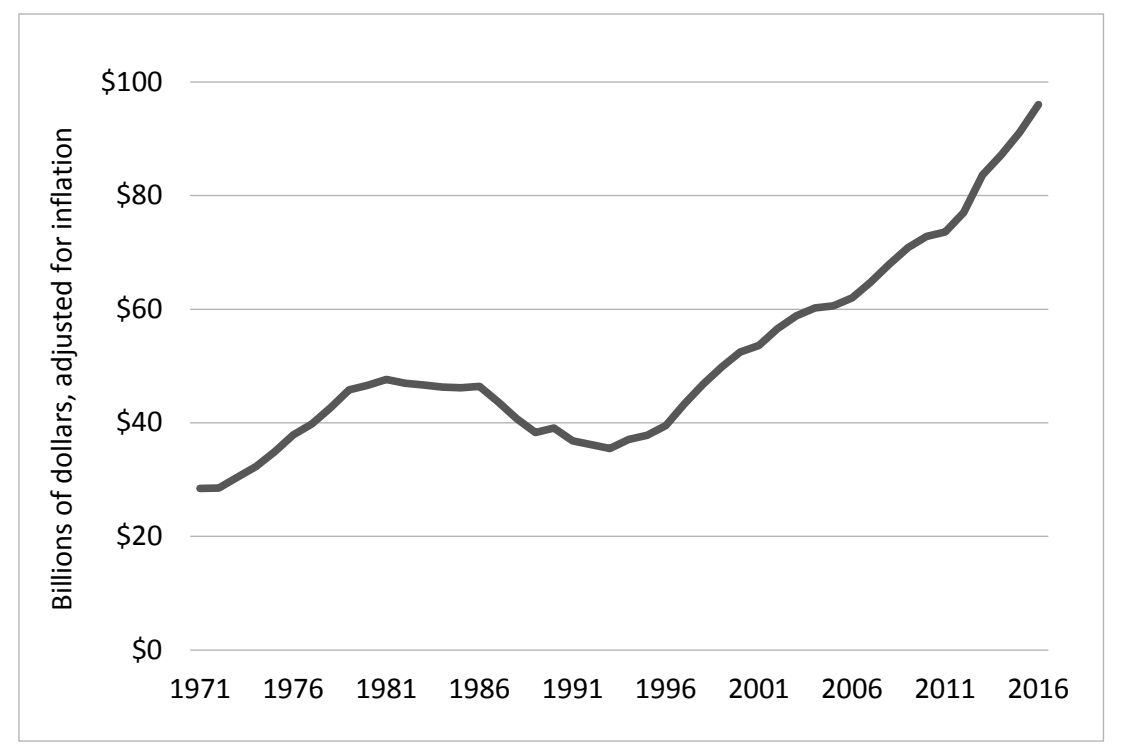

Sources: Statistics Canada (2018h)

In relation to rising farm debt, it is often pointed out that the values of farmers' assets, especially farmland, are rising as well (FCC, 2017). Thus, some would argue that farm debt, relative to assets, is less of a problem than debt numbers alone might indicate. This view, however, ignores the fact that debt must be repaid from net income, not from asset values (except in the case of farm bankruptcy or the farm family exiting the sector). As we show above and below, net farm income is increasingly inadequate to support farm families and repay farm debt.

Most troubling perhaps, farmers are now paying about \$3 billion per year in interest charges (Statistics Canada, 2018d). The amount that farmers paid in interest during the farm income crisis period (circa 1986 to present) totals $\$ 93$ billion dollars (all figures adjusted for inflation). Over that same 31-year period, Canadian taxpayers transferred to farmers, via farmsupport programs, $\$ 102$ billion dollars. The amount that Canadian taxpayers have paid to farmers approximately equals the amount that farmers have paid to banks and other lenders.

\section{Declining prices}

Adjusted for inflation, the prices farmers receive for their crops and livestock are, in recent decades, a fraction of the prices one or two generations ago. Figure 6 shows the situation for farmers who grow wheat and it includes a trend line. The year 1985-roughly the beginning of the farm income crisis - is marked by a white dot. From the end of the Depression until the mid- 
1980s, the inflation-adjusted price of wheat seldom dropped below $\$ 10$ per bushel, and it occasionally spiked above $\$ 20$. Since the mid-80s, however, the price has remained below $\$ 10$, often falling below $\$ 5$. Figure 7 shows a similar situation for cattle producers: long-term price declines.

Figure 6: Wheat prices, representative western Canadian prices at country elevators, 1913 to 2016

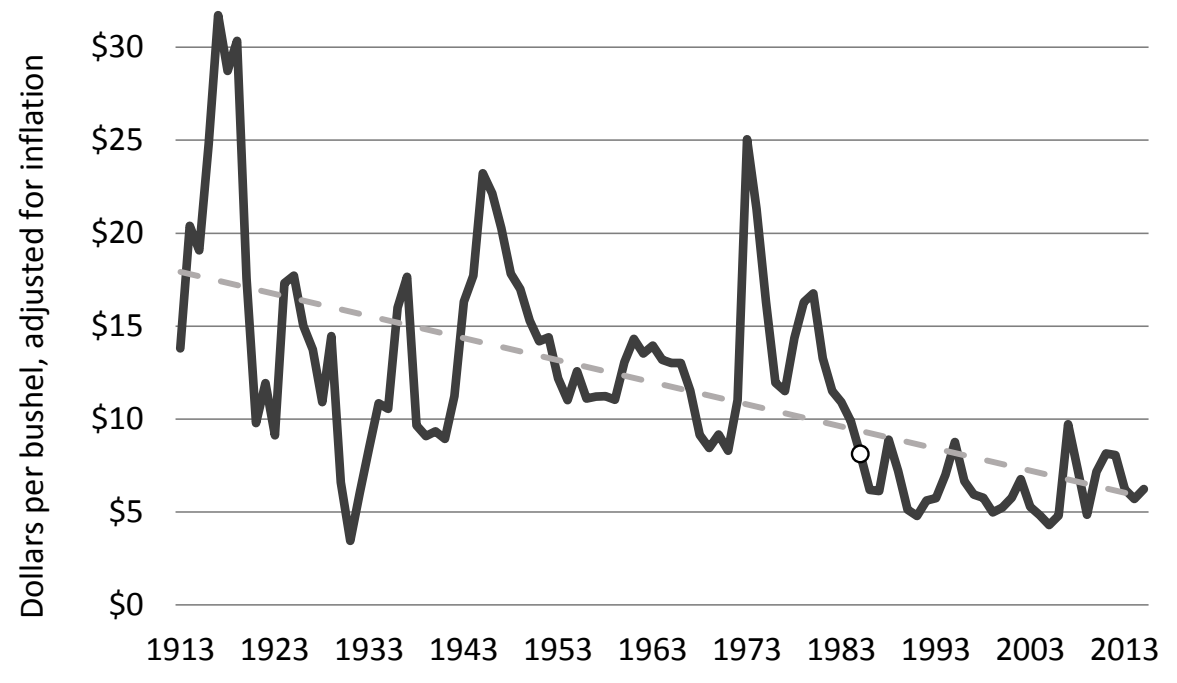

Sources: Leacy, Urquhart, and Buckley (1983); Saskatchewan Agriculture and Food (2006); Statistics Canada (2018i)

Figure 7: Manitoba slaughter cow and Ontario slaughter steer prices, 1913 to 2016

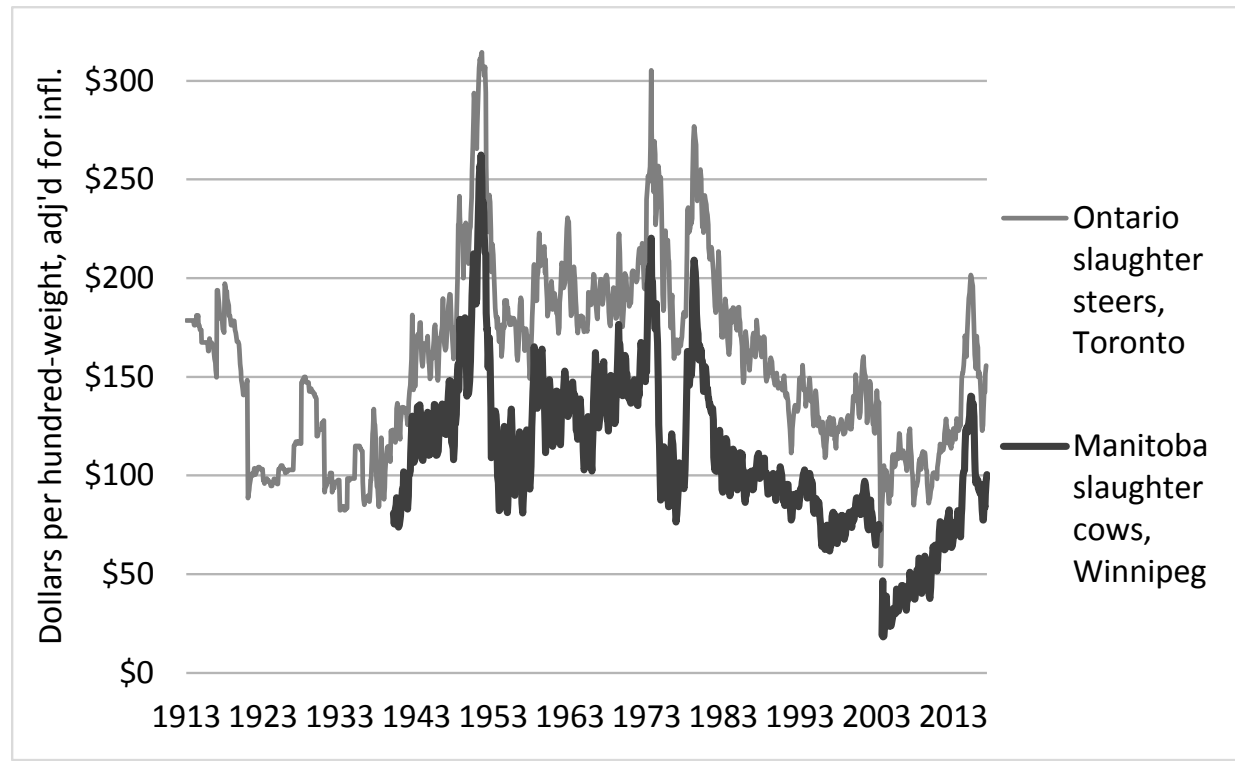

Sources: Long-term timeseries assembled from various printed and online sources including Statistics Canada (2018i; 2018j), Statistics Canada (1984), and Manitoba Agriculture (2008; 2018).

More detailed source notes available upon request. 


\section{Who owns what?}

\section{Land: rising prices and shifting ownership patterns}

In addition to low net farm income, challenges in accessing farmland create barriers to the entry or retention of young farmers. Indeed, there are two related problems with farmland: rising prices, on the one hand, and, on the other, changing patterns of ownership, including increasing land concentration among fewer farmers, demand for farmland for non-farm uses, and increasing ownership by investors.

Farmland purchases by non-farmer investors has been well documented (Desmarais, Qualman, Magnan, \& Wiebe, 2015, 2016; National Farmers Union, 2015). Increasingly, farmers are having to bid against investors to purchase farmland. With Canadian farmland allocated according to ability to pay, and with prices increasingly untethered from the productive capacity of the land, it is new and young farmers who are most excluded from ownership. Investor purchases are both a cause and an effect of rising land prices.

The rise in farmland prices and the effect that this is having on young farmers is evident to all. In a May 2017 report, Statistics Canada noted that "In 2016 the average value of land and buildings was \$2,696 per acre, which is an increase of 38.8 percent from 2011 (in 2016 constant dollars). This cost is ever increasing, and can be a barrier to starting or expanding an agricultural operation”. The report notes that "Young farmers [are] more likely to rent land than to own it." The report continues:

Of agricultural operations where all operators were under the age of $35,50.6 \%$ rented land from others, compared with $35.1 \%$ of all agricultural operations. On agricultural operations that used only rented land, the average operator age was 46.0 years, 9 years younger than the national average. (Statistics Canada, 2017)

Evidence suggests that Canada may be actually in the midst of a farmland-price bubble: a period of rapidly rising asset prices, unsupported by economic fundamentals, which risks ending in a price contraction. Over the past decade-and-a-half, prices have risen more, and faster, than at any time in Canadian history. Figures 8 and 9 show the past 90 years of data on the value of farmland and buildings in Alberta, Saskatchewan, Manitoba, Ontario, and Quebec. Although the data captures the value of both land and the farm buildings on it, the value of the land far outweighs the value of buildings when aggregated across provinces. Thus, this data can be used as a proxy for land prices, and certainly for changes in prices.

Taking Ontario as an example, Figure 8 shows that the average value of farmland in that province remained below $\$ 4,000$ per acre for most of the eight-decade period before 2001 (all figures adjusted for inflation). The average value in 2016 was \$10,600. Figure 9 shows similar data for Alberta, Saskatchewan, and Manitoba. (Note that the two figures use different Y-axis 
scales, a reflection of the different price regimes in the two regions.) Figure 9 shows similarly large land price increases in the Prairie Provinces. In Manitoba, for example, farmland prices in the 30 years from 1977 to 2006 averaged \$720 per acre. In 2016, the average price was two-anda-half times as high, and rising on a steep trend line. This rapid land-price escalation, combined with record-high farm debt, an aging farm population, chronically low net farm income, and the perennial need for billions in farm-support payments, should raise concerns. If we add in climate change impacts and the need to retool the planet's energy and food systems in order to slash emissions by mid-century, perhaps alarm bells should be ringing.

High farmland prices pose an especially difficult problem for new farmers and young farmers. The cost of an acre of land is rising, but the net farm income generated by that acre- the money that could be used to pay for that land-is not. This means that it gets harder and harder to pay for land by farming that land. Increasingly, new land must be paid for from the proceeds from the existing (i.e., paid for) land base. This means that while large farms can pay top dollar for land, it is impossible for small or new farmers to make farmland purchases "pay."

Figure 8: Value of land and buildings, Ontario and Quebec, 1921 to 2016

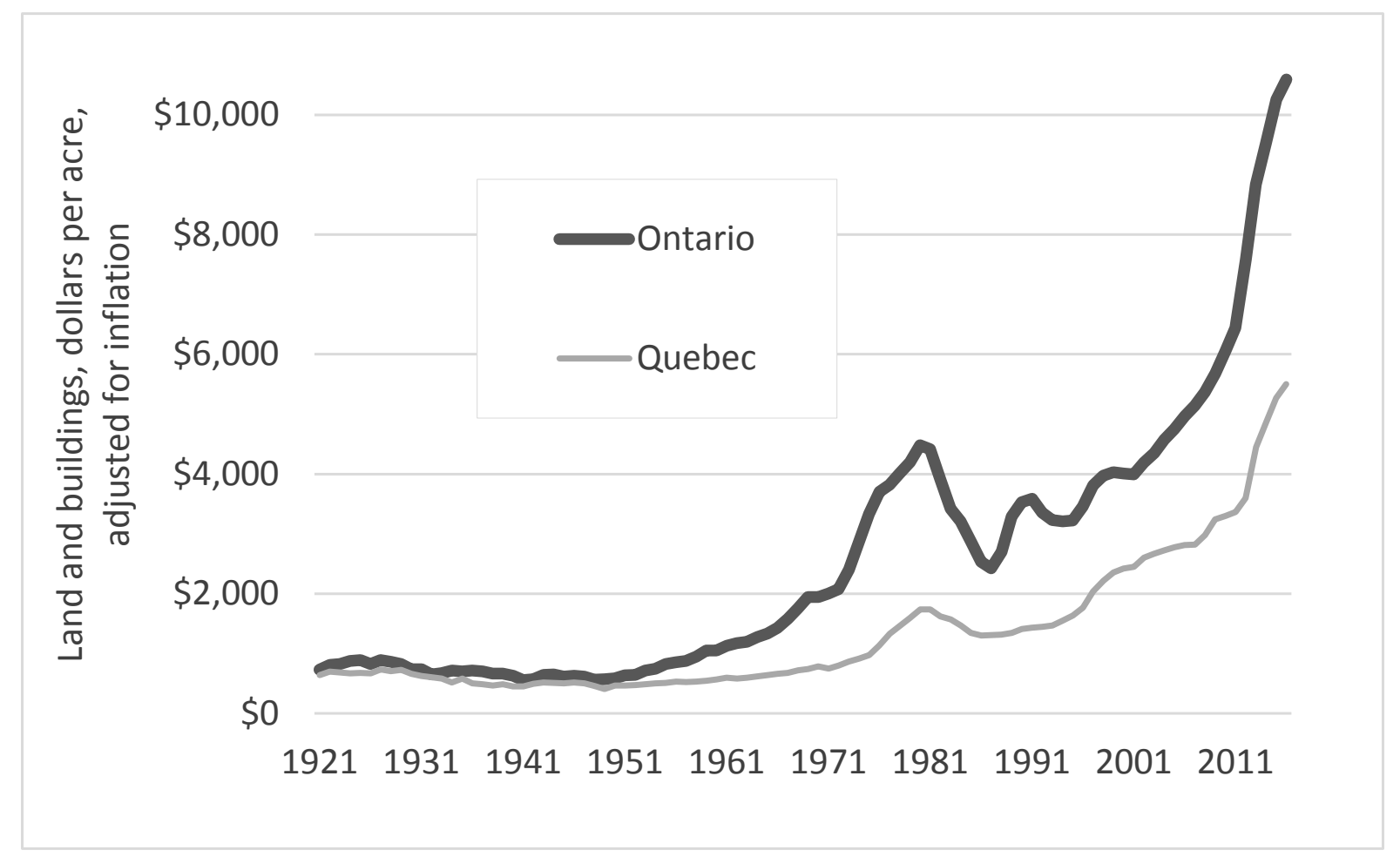

Sources: Statistics Canada (2018k) 
Figure 9: Value of land and buildings, Manitoba, Alberta, and Saskatchewan, 1921 to 2016. Note differing axis scales

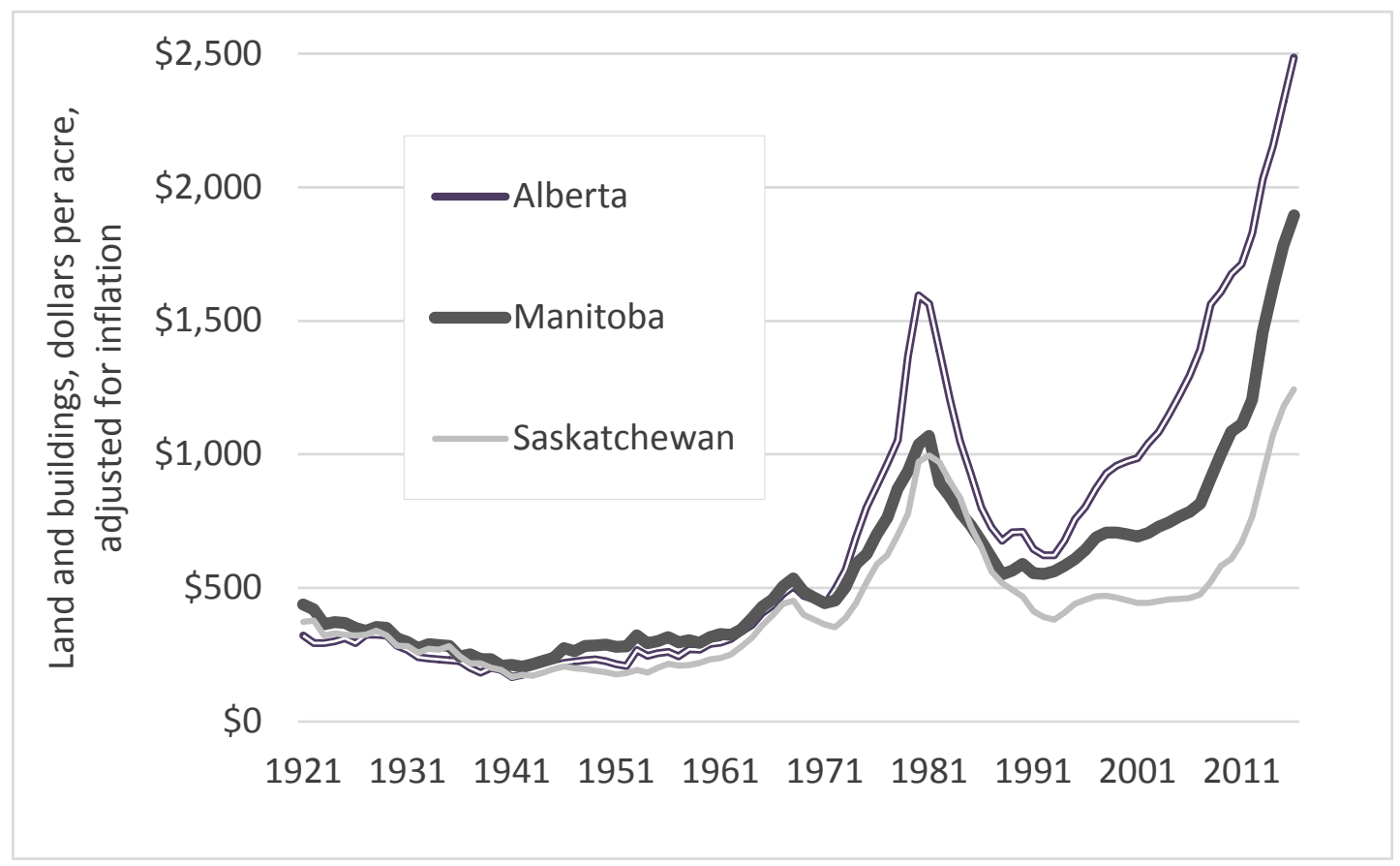

Sources: Statistics Canada (2018k)

Table 1: Realized net farm income and farmland prices, decade-averages, adjusted for inflation, per acre, Ontario and Manitoba, 1920s to 2010s. Note that realized net farm income here includes farm support payments. All figures adjusted for inflation.

\begin{tabular}{|c|c|c|c|c|c|c|}
\hline \multirow[b]{2}{*}{ Decade } & \multicolumn{3}{|c|}{ Ontario } & \multicolumn{3}{|c|}{ Manitoba } \\
\hline & $\begin{array}{l}\text { Realized net } \\
\text { farm income, } \\
\text { subsidies } \\
\frac{\text { included }}{\text { acre) }} \text { (Per }\end{array}$ & $\begin{array}{l}\text { Price of land } \\
\text { (and } \\
\text { buildings) (per } \\
\text { acre) }\end{array}$ & $\begin{array}{c}\text { Cents of net } \\
\text { income per } \\
\text { dollar of } \\
\text { farmland cost }\end{array}$ & $\begin{array}{l}\text { Realized net } \\
\text { farm income, } \\
\text { subsidies } \\
\frac{\text { included }}{\text { acre) }} \text { (Per }\end{array}$ & $\begin{array}{l}\text { Price of land } \\
\text { (and } \\
\text { buildings) (per } \\
\text { acre) }\end{array}$ & $\begin{array}{c}\text { Cents of net } \\
\text { income per } \\
\text { dollar of } \\
\text { farmland cost }\end{array}$ \\
\hline $1920 \mathrm{~s}$ & $\$ 80$ & $\$ 840$ & 9.5 & $\$ 36$ & $\$ 373$ & 9.6 \\
\hline $1930 \mathrm{~s}$ & $\$ 51$ & $\$ 698$ & 7.3 & $\$ 16$ & $\$ 271$ & 5.9 \\
\hline $1940 \mathrm{~s}$ & $\$ 128$ & $\$ 606$ & 21.2 & $\$ 74$ & $\$ 241$ & 30.8 \\
\hline $1950 \mathrm{~s}$ & $\$ 121$ & $\$ 790$ & 15.3 & $\$ 53$ & $\$ 298$ & 17.8 \\
\hline $1960 \mathrm{~s}$ & $\$ 120$ & $\$ 1,388$ & 8.7 & $\$ 49$ & $\$ 411$ & 12.0 \\
\hline $1970 \mathrm{~s}$ & $\$ 143$ & $\$ 3,036$ & 4.7 & $\$ 56$ & $\$ 636$ & 8.7 \\
\hline $1980 \mathrm{~s}$ & $\$ 96$ & $\$ 3,325$ & 2.9 & $\$ 29$ & $\$ 776$ & 3.8 \\
\hline 1990s & $\$ 33$ & $\$ 3,541$ & 0.9 & $\$ 14$ & $\$ 620$ & 2.3 \\
\hline $2000 \mathrm{~s}$ & $\$ 23$ & $\$ 4,824$ & 0.5 & $\$ 21$ & $\$ 813$ & 2.6 \\
\hline $\begin{array}{c}2010 s \\
\text { (until 2016) }\end{array}$ & $\$ 83$ & $\$ 8,468$ & 1.0 & $\$ 31$ & $\$ 1,453$ & 2.1 \\
\hline
\end{tabular}

Sources: Statistics Canada (2018e; 2018k) 
Farmland affordability can be evaluated as a measure of the price of that land relative to the net returns it can generate- - a ratio of the per-acre cost of the land and its per-acre net returns. Seen this way, farmland today is very unaffordable.

Table 1 lists realized net farm income per acre and the cost of farmland (and associated buildings) per acre in two representative provinces: Manitoba and Ontario. The figures are adjusted for inflation and listed as averages for each decade. For example, in the 1950s in Ontario farmland prices averaged \$790 per acre and realized net farm income (with state subsidies included in this case) averaged \$121 per acre. The third column for each province calculates the ratio of net farm income to farmland prices and lists the number of cents of net farm income generated from a dollar's-worth of purchased land. For example, in the 1950s, for every dollar an Ontario farmer spent on farmland, on average, that land would generate an additional net return of 15 cents with which he or she could hope to pay off that land.

What Table 1 reveals regarding the relative affordability of farmland is astonishing. Looking first at Ontario: In the 1970s, for example, for every dollar a farmer spent on farmland, he or she could hope to generate 4.7 cents in net returns. Over the past two-and-a-half decades, that number has fallen to about 1 cent in Ontario (0.9 cents in the 1990 s, 0.5 cents in the 2000s, and one cent in the 2010s).

The relative affordability of farmland has similarly declined in Manitoba. In the 1970s, for example, if a farmer spent a dollar on farmland, that same land would, on average, generate 8.7 cents in net farm income with which a farmer could pay off that land. Over the past two-anda-half decades, however, net incomes have fallen and land prices have risen such that farmers now generate just two to three cents in net income for every dollar they spend on land. Table 1 clearly demonstrates that a young farmer with a small land base has little chance of paying for farmland. If, for example, he or she bought \$500,000 worth of farmland in Ontarioabout 60 acres at current prices - that young farmer could expect to generate only $\$ 5,000$ in net farm income from those acres. Unless a farmer has a large land base already paid for, he or she has little hope of servicing debt on farmland bought at current prices.

\section{Costs of machinery and capital}

In addition to land costs, young and new farmers face another barrier: high costs for machinery and other capital equipment. At the extreme, machinery costs have risen to astronomical levels. For example, for grain and oilseed producers, the largest pieces of seeding equipment can, generously optioned, cost more than \$1 million (e.g., the Bourgault 3420-100 air drill and 71300 seed cart). These large seeders must be pulled by tractors that themselves cost hundreds-ofthousands of dollars, the combine to harvest the crop can cost another million dollars, a large sprayer half-a-million, and a line of trucks and supporting equipment another half-million, or more.

Admittedly, these prices are for the largest new equipment-machines that few farmers buy and perhaps no young farmer could afford, or would want to purchase. But more modest 
equipment is also costly. Each year the Manitoba government publishes its "Guidelines for Estimating Crop Production Costs” (Manitoba Agriculture, 2017). The 2017 edition models the costs for a 2,000-acre grain farm. Total machinery cost for that farm is listed at $\$ 993,125$. This assumes a limited and practical line of farm equipment (e.g., one large and two small tractors with a total value of \$270,000). Even assuming this sort of smaller, used equipment, the machinery requirement is nearly $\$ 500$ per acre. At that cost, a small or medium-sized farm might require hundreds-of-thousands of dollars' worth of machinery (in addition to perhaps one or two million dollars' worth of land). While machinery costs will be lower for livestock producers, these costs will still be high, relative to net returns. These rising capital requirements are partly a result of the production-maximization focus examined below, and increasingly financed by the rising debt levels discussed above. They have important implications for the pattern of work in agriculture.

\section{Who does what?}

The scale of farm machinery: The technological expulsion of farmers?

In this article, we argue that reduced profitability leading to low net farm income is the primary reason that Canada has lost one-third of its farmers and two-thirds of its young farmers in just a single generation. There is, however, another explanation proffered by many in government, industry, and academia: advancing technology and ever larger, more productive farm machinery means that we simply need fewer farmers on the land. An agriculture based on 100-horsepower tractors and 30-foot implements needs a certain number of operators; one based on 500-hp tractors and 70-foot implements needs far fewer. Similarly, on the livestock side, more productive haying and feeding machinery means that the same number of animals can be raised by fewer farmers. The story that large equipment and advancing technology allows farmers to produce more food with fewer people seems initially compelling and certainly contains some truth. But it also turns out to be misleading in many ways. For example, it implies that Canada, the US, and similar nations are producing food using fewer and fewer people.

This initial assessment, however, does not adequately take into account growth in employment in seed, chemical, machinery, farm-retail and wholesale, and technology companies. Seed-genetics-chemical-technology companies such as Bayer-Monsanto ${ }^{2}$ are very complex entities employing office towers and research parks full of chemists, patent attorneys, human resources managers, process engineers, public relations experts, lobbyists, janitors,

\footnotetext{
2 On June 7, 2018, Bayer finalized its acquisition of Monsanto. Bayer has since dropped the name Monsanto in announcing that "the company will be referred to as Bayer after the integration begins, the Monsanto legal entity structure will remain in place until a legal entity consolidation process can be completed” (Bayer, 2018).
} 
geneticists, and a host of other specialized workers. Many of these workers are products of universities or technical schools-entities that are themselves highly complex with large staffs. These Bayer and former Monsanto employees use computers that are products of complex, globe-encircling supply, production, and marketing chains. These genetics-seed-chemicaltechnology companies are owned by millions of shareholders, and company shares and bonds are traded within global financial systems, which themselves absorb huge amounts of labour. To these employees of large agribusiness transnationals, we can add a growing cadre of other farmer-support employees: accountants, agronomists, and market analysts, to name a few.

It is beyond the scope of this paper to provide a complete analysis on overall employment in all farm input, production and support sectors in North America, but such an analysis is not entirely necessary. As a starting point, it is enough to know that low net farm incomes, increasing land concentration, and very high capital requirements have reconfigured employment within Canadian agriculture. Even as we employ fewer and fewer farmers (and often call this "efficiency") employment in agricultural input corporations and support services is increasing (though this is seldom labelled as "inefficiency"). One can come at this same idea from another way: Canadian farmers now produce nearly $\$ 60$ billion per year in farm products. Farmers keep less than $\$ 3$ billion of this and seed, chemical, fertilizer, and machinery companies and other input and service suppliers take the other $\$ 57$ billion. And that huge amount of money is used to pay wages, salaries, bonuses, rent, interest, incentives, dividends, patent royalties, and capital appreciation to tens- or hundreds-of-thousands more people.

While the conventional story is that larger and more sophisticated machinery and a broader range of high-tech inputs allow us to farm with fewer people, the real story is that these agribusiness products serve to shift employment off of our farms and onto the payrolls of the dominant corporations, just as these same machines, technologies, and products have served to shift profits. Indeed, a young man or woman from a farm background can obtain stable, longterm employment with an agribusiness company_as an agrologist, machinery technician, seed breeder, or fertilizer-plant worker-more easily and securely than he or she can enter farming.

\section{Corporate power in the agri-food chain}

There are many ways to analyze and measure the growing market power of agribusiness transnationals. One can focus on mergers between companies and even between sectors-for example, the seed and chemical sectors, formerly separate, have been merged. One can document growing concentration-fewer firms controlling a sector-and the attendant erosion of competitive disciplines on prices and profits. Or, one could also look at the sheer size and growth-rates of these firms. Monsanto, for example, was three times larger in 2017 than it was fifteen years earlier, and the merged Bayer-Monsanto entity is several times larger still.

But perhaps the best way to highlight the immense and growing market power of these corporations is to document their success in taking an ever-larger share of food-system dollars for themselves - charging farmers more for inputs, paying farmers less for crops and livestock, 
charging consumers more in grocery stores, and pocketing more for themselves (NFU, 2005; Winson, 1993, 2013). This reveals their effective power. Profit is the ultimate purpose, measure, and proof of market power.

As detailed above, net farm income from the markets is near zero in many years because farmers have low market power relative to input makers, and this empowers those companies to capture almost all of Canadian farm revenues. But there is another arena in which market power battles are played out - downstream from farmers, where citizens' grocery-store dollars are divvied up. Farmers' dwindling share of those dollars reflects the growing market power of meat packers, food processors, retailers, and restaurant chains.

As an example, Figure 10 shows the continuously growing gap between what consumers pay for corn flakes and what farmers receive for the corn that goes into the processing plant and into the box. The gap between farm and retail prices equals the amount that grain companies, processors, and retailers take for themselves. And that amount is doubling and redoubling-a reflection of the rising market power of the non-farm links in the agri-food chain. To paraphrase papers by Canada's National Farmers Union (2007): young farmers are making too little because others in the agri-food chain are taking too much. Similar to Figure 10, Figure 11 shows a growing gap between what Canadians pay for bread and what farmers in western provinces such as Saskatchewan receive for wheat. That rapidly widening gap is a direct reflection of rapidly growing corporate power.

Figure 10: Ontario corn, delivered to elevator, and corn flakes, Canada average retail price, 1976 to 2016

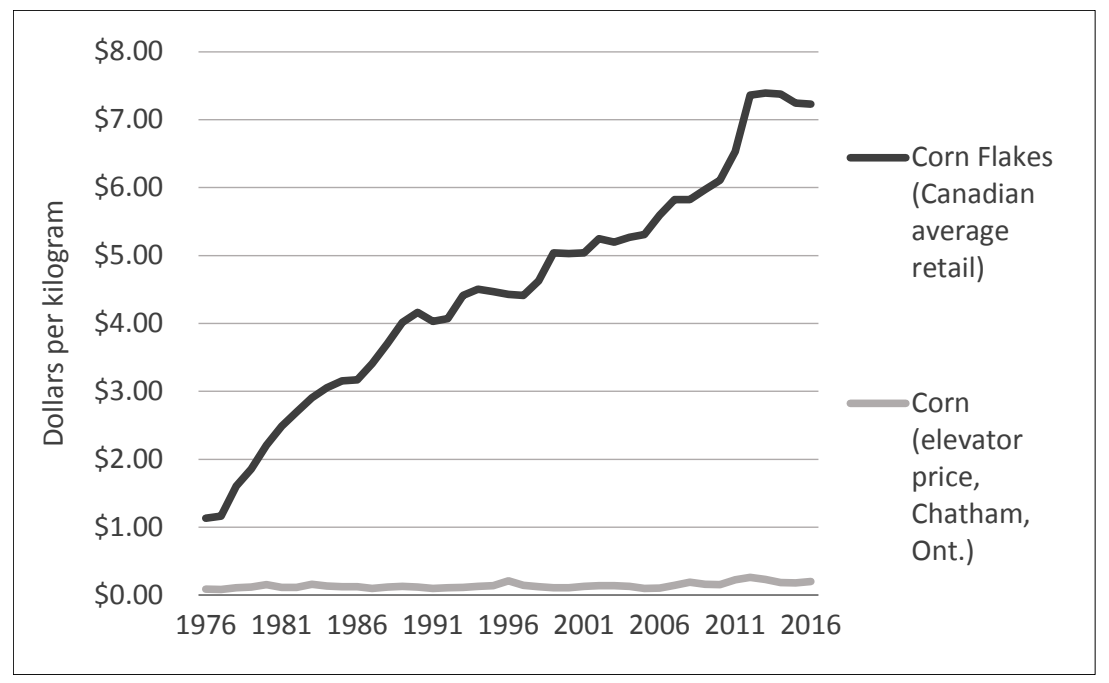

Sources: Statistics Canada (2018l), Canada Grains Council (1996; 2006), Ontario Ministry of Agriculture, Food and Rural Affairs (2017a; 2017b)

It is possible to produce a large number of similar graphs in which retail prices rise but farm-gate prices remain stagnant. Graphs for steers and steaks, hogs and pork chops, barley and beer, and nearly all other farm/retail pairings look nearly identical to the "wedge" graphs depicted above. Farmers, young and old, are caught in a pincer: on one side, increasingly powerful processors 
and retailers use their power to take an ever-larger share of grocery-store dollars for themselves, passing a diminishing share back to farmers; and, on the other side, increasingly powerful input makers use their market power to take from farmers an ever larger share of the money that does make it back to the farm. This asymmetry in market power is an important factor affecting the incomes of farmers, young and old.

Figure 11: Western Canadian wheat price, elevator net, and bread price, Canada average retail, 1976 to 2016

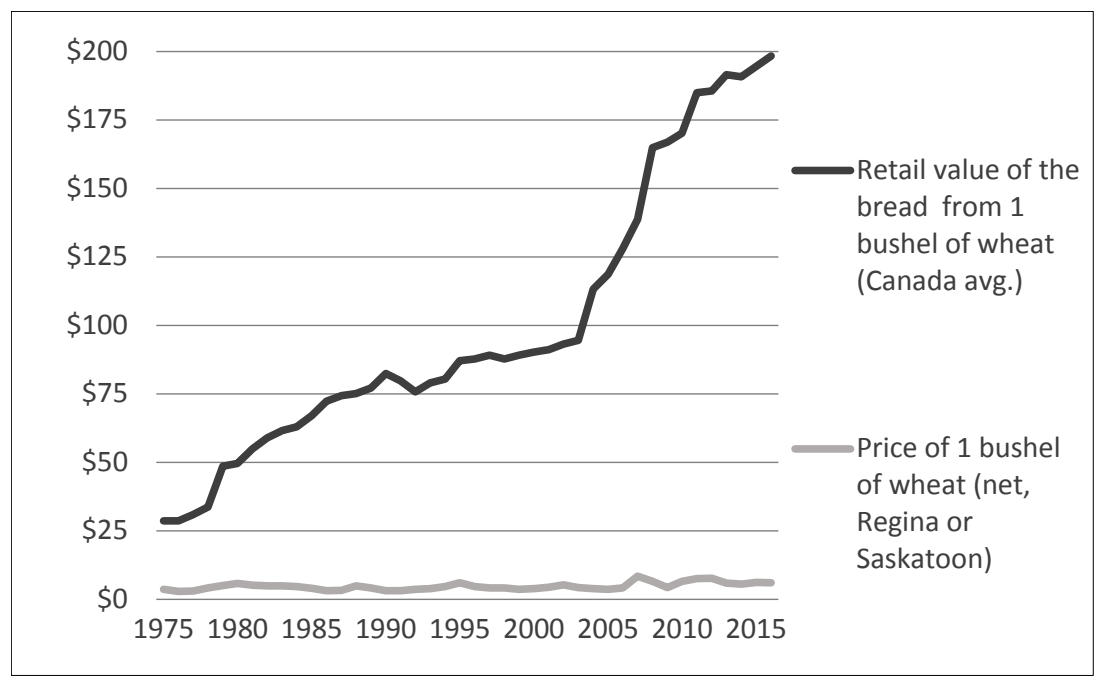

Sources: Statistics Canada (1998; 2018i; 2018l), Saskatchewan Agriculture and Food, (2006)

What is the role of the state?

A focus on production for export

Young farmers are few because net incomes are low. Net incomes are low because the market power of farmers is weak. Corporate power in the agri-food chain has restructured employment away from production and toward input and support sectors. To this analysis, we can add another key factor. Globalization of agricultural markets and state policies focused on maximizing trade and exports further erode farmers' power and incomes. This occurs for at least five reasons:

1. Policies designed to maximize exports have the secondary effect of encouraging maximum production. Such an approach encourages farmers to maximize input use, and overdependence on purchased inputs erodes farmers' net incomes because the prices of purchased inputs are rising more rapidly than the prices of farm products. In sum, export maximization pushes farmers toward productivism, and this makes them vulnerable to agribusiness extractivism.

2. Globalizing agricultural markets puts Canadian farmers into competition with all the farmers of the world. Increasing production in global commodity markets results in what economists 
call the "fallacy of composition": as you produce more in globally competitive markets, the price drops. At the same time, at the other links in the agri-food chain, agribusiness corporations are merging, to lower the competition they face. As competition levels increase for farmers and decrease for agribusiness corporations it is easy to predict shifts in relative profitability. The relative shifts in profitability are due to agribusiness not only enhancing monopolistic tendencies in markets, but also rent-seeking in concentrated markets- the manipulation of markets to enhance corporate profits, not to create new wealth.

3. Grain companies, commodity traders, and processors can take advantage of globalized markets and trade agreements to move commodities from one nation to another, thereby disciplining prices in any region where they might rise. The mere threat of such imports can cause prices to fall. This is what Philip McMichael (2009) refers to as world market prices acting as a discipline.

4. As exports rise, so do imports, often in lock-step. Canadian agri-food exports are rising, but so too are imports. The difference between the two — net exports—is today about the same as it was in the early- and mid-1980s: about \$11 billion (all figures adjusted for inflation). Thus, looking only at the expansion of agri-food exports overstates the benefits to Canadian farmers. More research is needed to quantify the extent to which Canadian farmers are gaining markets, and the extent to which they are merely exchanging markets - swapping dependable, easy-to-access, low-transport-cost Canadian markets for inferior ones overseas.

5. Policies to maximize Canadian exports are in lock-step with long-standing efforts to make Canada a resource superpower. Food is one of those resources.

Figure 12: Canadian agri-food exports and net farm income, 1970 to 2016

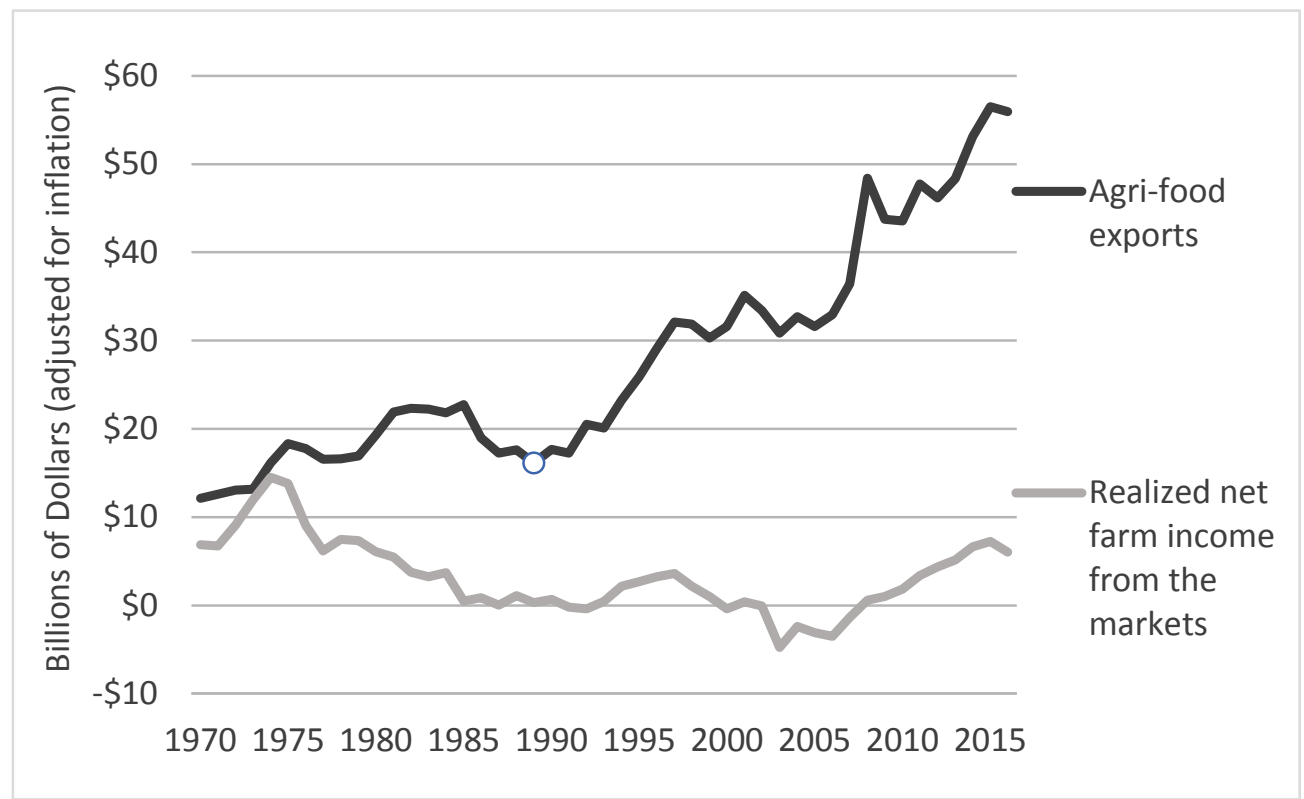

Sources: Statistics Canada (2018e; 2018f), Agriculture and Agri-Food Canada (1996; 2016) 
While Canadian agriculture has always been export focused, since the early 1990s there has been a renewed push by the federal government toward export maximization. The story-line advanced by federal and provincial governments is that Canada must be a top-tier food exporter; we must feed the world; and if we succeed in increasing exports, everyone will benefit. As Figure 12 demonstrates, however, Canada's success in doubling and redoubling agri-food exports has not helped farmers or their net incomes. Again, this is predictable. As Canadian farmers and the commodities they produce are forced to face increased competition, prices in Canada and elsewhere will fall. Figure 12 shows Canadian agri-food exports and net farm income covering the period from 1970 to 2016. The units are billions of dollars, adjusted for inflation. A round circle on the upper line highlights 1989, which marked the beginning of the modern "free trade" period. In 1989, Canada implemented the Canada-US Free Trade Agreement. Not long after, we implemented the North American Free Trade Agreement and the World Trade Organization Agreement on Agriculture.

In addition to signing trade agreements, Canada's governments have set, and met, ambitious export-expansion targets. In April 2017, Canada’s federal government announced a target for higher agri-food exports: $\$ 75$ billion by 2025 (Gov’t of Canada, 2017). This is just the most recent such target. In 1993, federal and provincial governments committed to double agrifood exports to $\$ 20$ billion by 2000 (Dakers \& Forge, 2000). Next, they pledged to double exports again, to $\$ 40$ billion by 2005 (Parliament of Canada, 1998). (This latter goal was actually suggested to the state by the Canadian Agri-Food Marketing Council, an industry group that represented Cargill, Maple Leaf, McCain, and other corporations.) Canada's trade-maximization policy agenda is, to a significant degree, a child of the dominant agri-food companies, and reflects corporate power in Canada's food system.

The post-1989 period has belied the idea that rising food exports will benefit all. Over that period, as exports tripled, farmer's net incomes stagnated, the number of Canadian farmers fell by a third, the number of young farmers was reduced by two-thirds, farm debt quadrupled, many Canadian-owned processing companies disappeared, and our agricultural and food systems became increasingly controlled by foreign corporations. It is likely that realigning Canadian agricultural policies toward a focus on serving local and regional markets would have far better outcomes for younger, smaller, and newer farmers - indeed for virtually all Canadian farmers. As evidence, we need only compare the relative prosperity of farmers who serve the Canadian domestic market (dairy, egg, and poultry producers) to farmers in the most export-focused sectors (hogs, cattle, and grains and oilseeds).

\section{Deregulation: turning Canada's farmers over to "markets forces”}

If we compare Canadian agricultural policies today to those of a generation ago, deregulation, privatization, and state realignment are all plainly visible. Beginning in the 1990s, Canada's federal government made it clear that it wanted Canadian farmers increasingly exposed to market forces and global competition. As an example of this consequential shift in state policy 
orientation, Table 2 provides a summary of the changes within Canada's grain handling and transportation system over the past generation.

Table 2: Canada's grain handling and transportation system—policy, regulatory, and marketing landscape, 1987 vs 2017

\begin{tabular}{|c|c|c|}
\hline & 1987 & 2017 \\
\hline $\begin{array}{l}\text { Railway } \\
\text { ownership }\end{array}$ & $\begin{array}{l}\text { Canadian National (CN) Railway was a } \\
\text { publically owned Crown corporation. }\end{array}$ & CN was privatized in 1995. \\
\hline $\begin{array}{l}\text { Grain } \\
\text { transportation } \\
\text { railway network }\end{array}$ & $\begin{array}{l}\text { Effective, public-interest controls on railway } \\
\text { branchline abandonment existed. }\end{array}$ & $\begin{array}{l}\text { Largescale branchline abandonment and } \\
\text { elevator closure began in the 1990s. }\end{array}$ \\
\hline $\begin{array}{l}\text { Railway freight } \\
\text { rates and grain } \\
\text { transportation } \\
\text { costs }\end{array}$ & $\begin{array}{l}\text { Grain freight rates were regulated and } \\
\text { farmers' costs were subsidized via the Crow } \\
\text { Benefit. }\end{array}$ & $\begin{array}{l}\text { The Crow Benefit ended in } 1995 \text { and } \\
\text { disciplines on freight rates continue to be } \\
\text { relaxed. }\end{array}$ \\
\hline Grain handling & $\begin{array}{l}\text { Co-operatives (Saskatchewan Wheat Pool, } \\
\text { Alberta Wheat Pool, and Manitoba Pool } \\
\text { Elevators) were the primary grain handlers in } \\
\text { western Canada. }\end{array}$ & $\begin{array}{l}\text { All co-op grain handlers were privatized in the } \\
\text { latter } 1990 \text { s and } 2000 \text { s. }\end{array}$ \\
\hline $\begin{array}{l}\text { Grain handling } \\
\text { and elevation } \\
\text { fees }\end{array}$ & $\begin{array}{l}\text { Country elevator handling fees were regulated } \\
\text { by the Canadian Grain Commission (CGC). }\end{array}$ & The regulation of fees ended in 1995 . \\
\hline Grain marketing & $\begin{array}{l}\text { Ontario Wheat Producers Marketing Board } \\
\text { (OWPMB) marketed all Ontario wheat, and the } \\
\text { Canadian Wheat Board (CWB) marketed all } \\
\text { western Canadian wheat, oats, and barley (for } \\
\text { human consumption). Profits were returned to } \\
\text { farmers. }\end{array}$ & $\begin{array}{l}\text { The OWPMB was terminated in 2003, and the } \\
\text { CWB in } 2012 \text {. }\end{array}$ \\
\hline Grain prices & $\begin{array}{l}\text { The Two-Price Wheat program paid farmers } \\
\text { significantly more for wheat used by Canadian } \\
\text { millers. }\end{array}$ & $\begin{array}{l}\text { The program was cancelled in } 1988 \text { in the } \\
\text { lead-up to the Canada-US Free Trade } \\
\text { Agreement (CUSTA) }\end{array}$ \\
\hline $\begin{array}{l}\text { Grain quality } \\
\text { assurance }\end{array}$ & $\begin{array}{l}\text { A strong Canadian Grain Commission (CGC) } \\
\text { regulated the Canadian grain quality system } \\
\text { "in the interest of producers." }\end{array}$ & $\begin{array}{l}\text { The CGC has been weakened and turned from } \\
\text { a regulator into an industry service provider. }\end{array}$ \\
\hline
\end{tabular}

Source: Western Producer, various dates

In addition to the changes listed in Table 2, the Canadian state has aggressively pursued new policies, deregulation, spending cuts, and privatization initiatives that have affected all aspects of Canadian agriculture, including farmers' rights to save and reuse seeds, the penetration by genetically modified seeds and foods, dairy marketing and processing co-operatives, investor ownership of farmland, and many other areas.

\section{What do (most) farmers do, and what do they get?}

\section{Off-farm employment and the household incomes of farm families}

Over the past 10 years (2007 to 2016, inclusive) realized net farm income from the markets has averaged \$3.5 billion per year (figures adjusted for inflation). According to the Census of 
Agriculture, Canada has about 200,000 farms and farm families. But if we do the math — divide net market income by the number of families-we get just $\$ 17,500$ each. Clearly, most of the money needed to sustain those 200,000 families must be coming from sources other than net farm income, especially given the fact that 20 per cent of farms capture 75 per cent of net farm income. The most recent data on farm family household income covers the period from 2001 to 2013, with the years 2010 and 2012 missing from Statistics Canada data. Figure 13 provides our first look at the makeup of total farm family income. Note that this data is for unincorporated farms only.

Figure 13: Overall income of farm families, average per farm/family, by source, unincorporated sector only, 2001 to 2013 (with some years omitted)

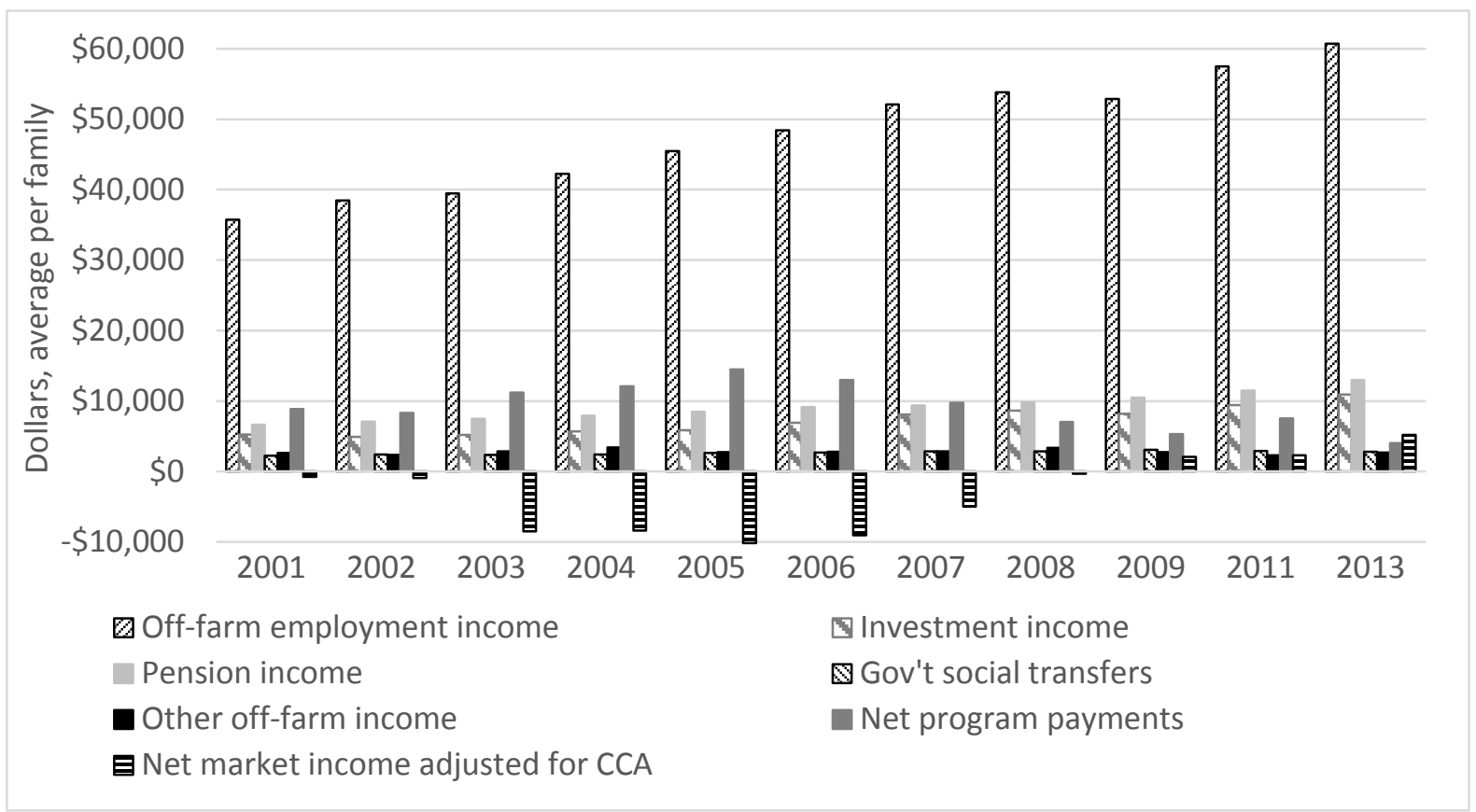

Sources: Statistics Canada (2018m)

Figure 13 reflects the ongoing farm income crisis. The post-2008 period is often characterized as "better times" for farmers. This is undoubtedly true for some as a number of farm families have prospered in recent years. On the whole, however, net farm income remains far below what might be needed to sustain even a fraction of Canada's 200,000 farms. The graph shows that even after 2008 off-farm employment income made up the bulk of farm family income: 52 percent. The next largest contribution to farm family household income was pension income, contributing 10 percent - a reflection of the advanced age of many Canadian farmers. Farm-support program payments contributed 6 percent. But net farm income (adjusted for capital cost allowance, i.e., to account for the value of depreciating assets such as machinery, and with farm-support payments subtracted out) contributed just two percent of farm family household income. 
Stated another way, despite a large reduction in the number of farms in Canada-from approximately 300,000 a generation ago to 200,000 today-agriculture is not even supporting that reduced number. Realized net farm income from the markets over the most recent decade averaged $\$ 3.5$ billion. Let us say that it takes $\$ 75,000$ in total annual income to support a family. At $\$ 75,000$ per family, $\$ 3.5$ billion could support only 47,000 farm families, not 200,000 . This fact reveals an existential threat to the majority of Canadian farm families: They operate in a sector that cannot financially support them.

Figure 14 shows the components of incomes for farm operators rather than farm families. Recall that there can be more than one operator per farm or farm family and many farms identify two or three operators on Census forms, often including spouses and older children. It is partly for this reason (multiple operators per farm) that the income values in this graph (of operators) are lower than those in the previous graph (for farms). Another reason for any variance is that this latter graph includes operators on all farms — incorporated and unincorporated — while the former includes only unincorporated farms. Figure 14 shows, again, that farmers generate most of their incomes from off-farm employment, program payments, and pensions. In the most recent 10 years included in the data (2005 to 2014, inclusive) net market income (adjusted for capital cost allowance) made up just six percent of overall farm operator income. Most of Canada's farmers can no longer rely on farming as the principal source of their livelihood.

Figure 14: Overall income of farm operators, average per operator, by source, unincorporated and incorporated sectors, 2001 to 2014

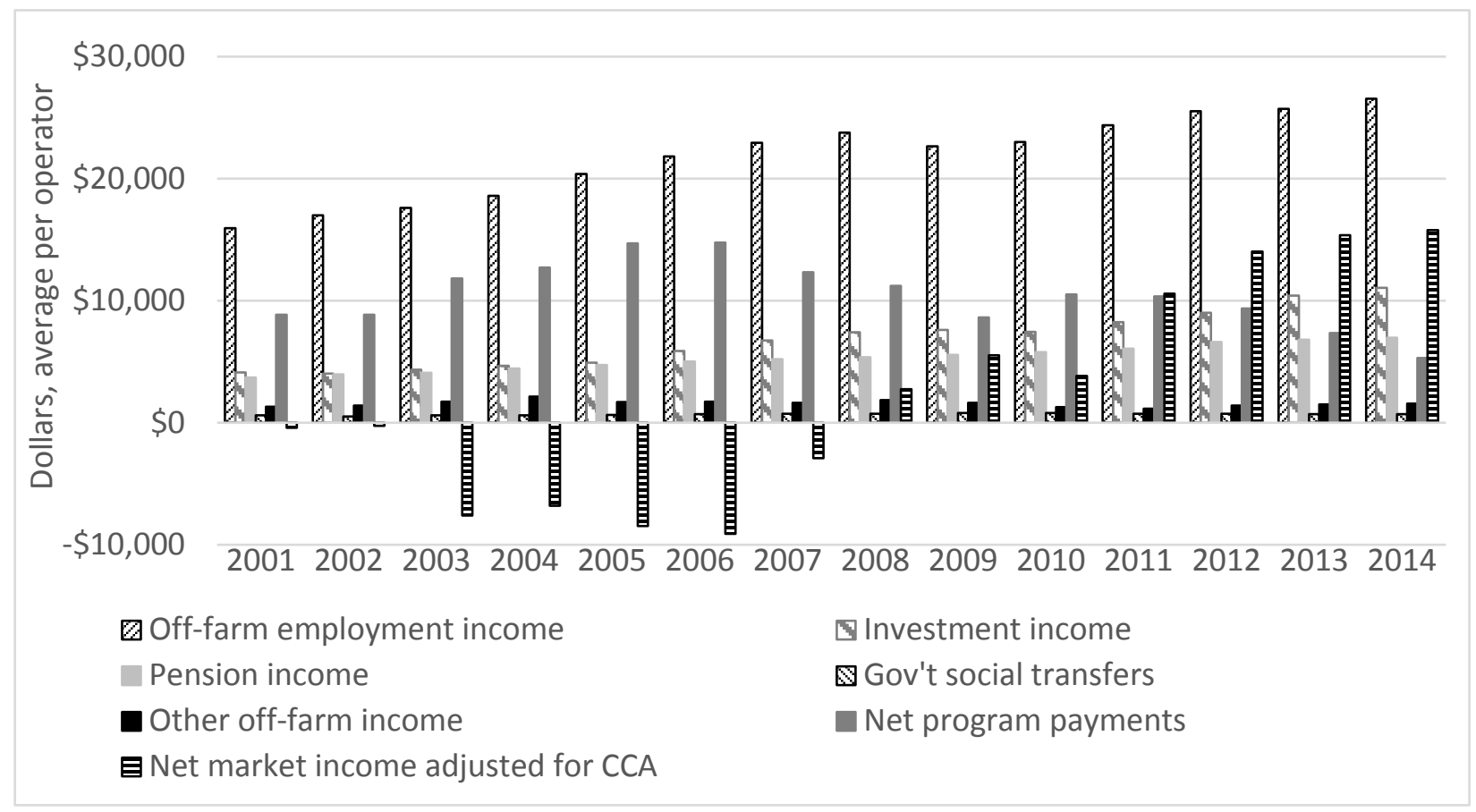

Sources: Statistics Canada (2018n) 


\section{Conclusion}

In a single generation, Canada has lost one-third of its farmers, and two-thirds of its young farmers. This article uses Bernstein's questions to frame an analysis of the making of a generational farm crisis. In doing so, we have revealed deep pathologies in the structure of Canadian agriculture. In terms of who gets what, we have shown that net farm income is inadequate, and distributed inequitably among farmers, with large and very large farms capturing almost all net income, while smaller farms, including those that many young and new farmers operate, earning low or negative net incomes. Low net farm incomes, rising land concentration, and very high capital requirements have led to a significant change in who does what in Canada's agriculture: fewer people are employed in farming, and more people are employed in input and support services. This reflects the capacity of agribusiness corporations to use their market power to take an ever larger share of food system wealth. And we have shown that this has led to a situation wherein most farmers, for their family income, must rely on off-farm work, pensions, and state subsidy payments. In terms of who owns what, we have shown that, relative to net income, farmland is increasingly unaffordable and so too are the machines and technologies needed to farm the land. Adding to Bernstein's questions, we have inquired into the role of the state in facilitating the structural changes in evidence and we have shown that state policies, too focused on export maximization and deregulation, have left farmers vulnerable and without adequate incomes, even as these policies have advanced the interests of agribusiness in Canada's agri-food chain.

Canadian agriculture is a paradox. By a great many measures our farms are extremely successful and productive. Farmers have managed to nearly double the value of their production since the early 1990s. Over the same period, the value of agri-food exports has more than tripled. Many measures of efficiency and productivity are up markedly, including output per acre and per farmer (all figures adjusted for inflation). Land markets are booming. And Canadian farmers are world-leaders in adopting cutting-edge production technologies. Thus, Canadian agriculture is not a failing sector. But it is failing many of the people in agriculture. Even as the system doubled its output and tripled its exports, it expelled two-thirds of young farmers. The full effects of the loss of so many energetic food producers have yet to be realised. But it is likely that as this reduced cohort moves through the coming decades, the total number of farms and farm families in Canada will fall dramatically, from its current level around 200,000 to perhaps fewer than 100,000 in the 2040s.

Moreover, this loss of stewards from the land has occurred with absolutely no offsetting benefits. The time is long past when factories were desperate for workers and the large number of people on the land had to be reduced for the economy to modernize and industrialize. With such a small percentage of Canadians still on farms the potential benefit of moving half (or more) of the remainder off the land is small. Additionally, policies aimed at reducing the number of farmers and making the sector "more efficient" have not delivered the benefit of lower food prices. In fact, the opposite has occurred. Even though farm prices have remained largely 
unchanged for decades, the prices Canadians pay for bread, cereals, meats, and other foods have increased significantly (Figures 10 and 11). Reducing the number of farmers has not made the sector more environmentally sustainable. In Canada and many other nations, ever-larger quantities of fossil-fuel-intensive inputs are being pushed into our food systems with the aim of pushing more food out the other end (Statistics Canada, 2018o).

It is hard to escape the conclusion that the renovation, retooling, and depopulation of Canada's farm sector has largely been directed and driven by the dominant agri-business companies, for the sake of their revenues and profits. And it has been facilitated (and often cheered or accelerated) by complicit or ill-informed politicians who rewrote the rules surrounding agriculture to please these corporations, all the while echoing platitudes about efficiency, exports, growth, globalization, market forces, and competitiveness. Seen this way, changes in agriculture over the past two generations are part tragedy and part swindle. As contradictory as it may seem, unfortunately, it is this destabilized, ill-regulated, and uncertain agricultural sector that some young Canadians are now seeking to enter or continue within.

Clearly, Canada needs a food system transformation. It is well worth carefully considering how this nation can restructure its food systems to welcome and support many more young farmers, keep existing farmers on the land, restore adequate incomes to all farm families, sustain rural communities, and move forward with the transformations of our farm and food systems that climate change is now forcing upon us.

Canada needs a new national food and agricultural policy framework built upon social, economic, and environmental sustainability. In working to develop such policies and frameworks, farmers, policy-makers, academics, experts, and citizens will have to explore a wide range of reforms and alternatives, including a greater emphasis on sustainable and low-input agriculture, local food, organic production, agro-ecology, and food sovereignty. The best and most legitimate way to build those new food and agricultural policies is through a democratic, inclusive, bottom-up process. The on-going work of Food Secure Canada (2017) to engage Canadians in developing a national food policy is one example of such a process, another is the People's Food Commission of the 1970s (Levkoe, 2014; People's Food Commission, 1980). The loss of two-thirds of young Canadian farmers in a generation highlights the failure of current government-corporate policies. While governments must continue to play a strong supporting role, the development of new food and agricultural policies for Canada must be organized and led by citizens, farmers, and their organizations.

\section{References}

Agriculture and Agri-Food Canada. (1996). Agri-Food export potential for the year 2000. Ottawa: AAFC. Retrieved from https://web.archive.org/web/19981205052358/http://atnriae.agr.ca:80/public/menu-e.htm 
Agriculture and Agri-Food Canada. (2016). Canada - At a glance. Ottawa: AAFC. Retrieved from http://www.agr.gc.ca/resources/prod/Internet-Internet/MISB-DGSIM/ATSSEA/PDF/4679.pdf

Bayer. (2018). Bayer \& Monsanto: advancing together as one. Retrieved from https://www.advancingtogether.com/en/home/

Beaulieu, M.S. (2014). Demographic changes in Canadian agriculture. Ottawa: Statistics Canada. Retrieved from http://www.statcan.gc.ca/pub/96-325-x/2014001/article/11905eng.pdf

Bernstein. H. (2010). Class dynamics of agrarian change. Halifax, N.S.: Fernwood Publishing.

Canada Grains Council. (1996). Statistical handbook. Winnipeg: Canada Grains Council.

Canada Grains Council. (2006). Statistical handbook. Winnipeg: Canada Grains Council.

Dakers, S., \& Forge, F. (2000). Agriculture: The policy agenda. Ottawa: Research Branch, Library of Parliament.

Desmarais, A.A., Qualman, D., Magnan, A., \& Wiebe, N. (2015). Land grabbing and land concentration: Mapping changing patterns of farmland ownership in three rural municipalities in Saskatchewan, Canada. Canadian Food Studies / La Revue Canadienne Des Études Sur L'alimentation, 2(1), 16-47.

Desmarais, A. A., Qualman, D., Magnan, A., \& Wiebe, N. (2016). Investor ownership or social investment? Changing farmland ownership in Saskatchewan, Canada. Agriculture and Human Values, 1(34), 149-166.

Farm Credit Canada (FCC). (2017). 2016 farmland values report. Ottawa: FCC. Retrieved from https://www.fcc-fac.ca/content/dam/fcc/about-fcc/reports/farmland-values-report2016.pdf

Food Secure Canada (FSC). (2017). Food policy. Retrieved from https://foodsecurecanada.org/policy-advocacy

Government of Canada. (2017). 2017 budget plan. Ottawa. Retrieved from https://www.budget.gc.ca/2017/docs/plan/budget-2017-en.pdf

Leacy, F.H., Urquhart, M.C., \& Buckley, K.A.H. (Eds.). (1983). Historical statistics of Canada (Second edition). Ottawa: Statistics Canada and the Social Science Federation of Canada. Retrieved from http://www.statcan.gc.ca/pub/11-516-x/3000140-eng.htm

Levkoe, C.Z. (2014). The food movement in Canada: A social movement network perspective. Journal of Peasant Studies, 41(3), 385-403. 
Manitoba Agriculture. (2008). Manitoba agriculture yearbook, 2008. Winnipeg: Manitoba Agriculture. Retrieved from https://www.gov.mb.ca/agriculture/markets-andstatistics/yearbook-and-state-of-agriculture/pubs/archive_yearbook_2008.pdf

Manitoba Agriculture. (2017). Guidelines for estimating crop production costs in Manitoba: 2017. Winnipeg: Manitoba Agriculture. Retrieved from http://www.gov.mb.ca/agriculture/business-and-economics/financialmanagement/pubs/cop-crop-production.pdf

Manitoba Agriculture. (2018). Agriculture Statistics Tables. Retrieved from https://www.gov.mb.ca/agriculture/markets-and-statistics/yearbook-and-state-ofagriculture/statistics-tables.html\#livestock

McMichael, P. (2009). The world food crisis in historical perspective. Monthly Review, 61(3), 32-47.

National Farmers Union (NFU). (2005). The farm crisis and corporate profits. Saskatoon: NFU. Retrieved from http://www.nfu.ca/sites/www.nfu.ca/files/corporate_profits.pdf

National Farmers Union. (2007). A brief to the Ontario Ombudsman from the National Farmers Union regarding the Ontario Ministry of Agriculture, Food, and Rural Affairs and its violation of its public trust. Saskatoon: NFU. Retrieved from http://www.nfu.ca/sites/www.nfu.ca/files/Ombudsman-OMAFRA.pdf

National Farmers Union. (2015). Losing our grip - 2015 update: Erosion of farmer autonomy and land ownership in Canada. Saskatoon: NFU. Retrieved from http://www.nfu.ca/issues/losing-our-grip-2015-update

Ontario Ministry of Agriculture, Food and Rural Affairs. (2017a). Estimated area, yield, production and farm value of specified field crops, Ontario, 2011 - 2015. Retrieved from http://www.omafra.gov.on.ca/english/stats/crops/estimate_new.htm

Ontario Ministry of Agriculture, Food and Rural Affairs. (2017b). Grain corn prices. Retrieved from http://www.omafra.gov.on.ca/english/stats/crops/price_grcorn.htm

Parliament of Canada. (1998). House of Commons, Agriculture Committee meetings, November 24, 1998. Retrieved from http://www.ourcommons.ca/DocumentViewer/en/361/AGRI/meeting-60/evidence

People's Food Commission. (1980). The land of milk and money: The national report of the People's Food Commission. Kitchener, ON: Between the Lines.

Saskatchewan Agriculture and Food. (2006). StatFacts, Canadian Wheat Board Final Price for Wheat, basis in store Saskatoon. Retrieved from https://web.archive.org/web/20090517004536/http://www.agriculture.gov.sk.ca:80/Defau lt.aspx?DN=02dcc904-ef01-4c82-b31c-816c7b2f29a3 
Statistics Canada. (1984). Livestock and Animal Products Statistics (Cat. No. 23-203). Ottawa: Statistics Canada.

Statistics Canada. (1998). Consumer prices and price indexes (Cat No. 62-010). Ottawa: Statistics Canada. Retrieved from http://www5.statcan.gc.ca/olc-cel/olc.action?objId=62$\underline{010-X \& o b j T y p e=2 \& l a n g=e n \& l i m i t=0}$

Statistics Canada. (2017). A portrait of a 21st century agricultural operation. Retrieved from http://www.statcan.gc.ca/pub/95-640-x/2016001/article/14811-eng.pdf

Statistics Canada. (2018a). Table 32-10-0152-01 Number and area of farms and farmland area by tenure, historical data (formerly CANSIM 004-0001). Retrieved from https://www150.statcan.gc.ca/t1/tbl1/en/tv.action?pid=3210015201

Statistics Canada. (2018b). Table 32-10-0169-01 Number of farm operators by sex, age and paid non-farm work, historical data (formerly CANSIM 004-0017). Retrieved from https://www150.statcan.gc.ca/t1/tbl1/en/cv.action?pid=3210016901

Statistics Canada. (2018c). Table 32-10-0045-01 Farm cash receipts, annual (x 1,000) (formerly CANSIM 002-0001). Retrieved from https://www150.statcan.gc.ca/t1/tbl1/en/tv.action?pid=3210004501

Statistics Canada. (2018d). Table 32-10-0049-01 Farm operating expenses (x 1,000) (formerly CANSIM 002-0005). Retrieved from https://www150.statcan.gc.ca/t1/tbl1/en/tv.action?pid=3210004901

Statistics Canada. (2018e). Table 32-10-0052-01 Net farm income (x 1,000) (formerly CANSIM 002-0009). Retrieved from https://www150.statcan.gc.ca/t1/tbl1/en/tv.action?pid=3210005201

Statistics Canada. (2018f). Table 32-10-0106-01 Direct payments to agriculture producers (x 1,000) (formerly CANSIM 002-0076). Retrieved from https://www150.statcan.gc.ca/t1/tbl1/en/tv.action?pid=3210010601

Statistics Canada. (2018g). Table 32-10-0070-01 Total and average off-farm income by source and total and average net operating income of farm operators by revenue class (formerly CANSIM 002-0036). Retrieved from https://www150.statcan.gc.ca/t1/tbl1/en/tv.action?pid=3210007001

Statistics Canada. (2018h). Table 32-10-0051-01 Farm Debt Outstanding, classified by lender (x 1,000) (formerly CANSIM 002-0008). Retrieved from https://www150.statcan.gc.ca/t1/tbl1/en/tv.action?pid=3210005101

Statistics Canada. (2018i). Table 32-10-0077-01 Farm product prices, crops and livestock (formerly CANSIM 002-0043). Retrieved from https://www150.statcan.gc.ca/t1/tbl1/en/tv.action?pid=3210007701 
Statistics Canada. (2018j). Table 32-10-0322-01 Average prices for selected classes and grades of cattle, monthly (formerly CANSIM 003-0068). Retrieved from https://www150.statcan.gc.ca/t1/tbl1/en/tv.action?pid=3210032201

Statistics Canada. (2018k). Table 32-10-0047-01 Farm land and buildings (formerly CANSIM 002-0003). Retrieved from https://www150.statcan.gc.ca/t1/tbl1/en/tv.action?pid=3210004701

Statistics Canada. (2018l). Table 18-10-0002-01 Monthly average retail prices for food and other selected products (formerly CANSIM 326-0012). Retrieved from https://www150.statcan.gc.ca/t1/tbl1/en/tv.action?pid=1810000201

Statistics Canada. (2018m). Table 32-10-0057-01 Total and average off-farm income by source (formerly CANSIM 002-0024). Retrieved from https://www150.statcan.gc.ca/t1/tbl1/en/tv.action?pid=3210005701

Statistics Canada. (2018n). Table 32-10-0068-01 Total and average off-farm income by source and total and average net operating income of farm operators (formerly CANSIM 0020034). Retrieved from https://www150.statcan.gc.ca/t1/tbl1/en/tv.action?pid=3210006801

Statistics Canada. (20180). Table 32-10-0039-01 Fertilizer shipments to Canadian agriculture markets, by nutrient content and fertilizer year, cumulative data (x 1,000) (formerly CANSIM 001-0069). Retrieved from https://www150.statcan.gc.ca/t1/tbl1/en/tv.action?pid=3210003901

Winson, A. (1993). The intimate commodity: Food and the development of the agro-industrial complex in Canada. Toronto: Garamond Press.

Winson, A. (2013). The industrial diet: The degradation of food and the struggle for healthy eating. Vancouver: University of British Columbia Press. 